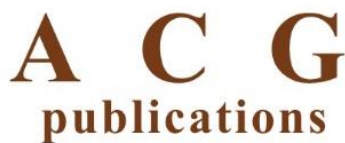

Org. Commun. 14:4 (2021) 323-333

\section{organic}

communications

\title{
Novel naphthalene-1,5-diamine containing urea/thiourea derivatives - Promising antimicrobial agents
}

\author{
Lachhireddy Venkataramana ${ }^{1}$, Reddi Mohan Naidu Kalla ${ }^{\circ}$ 2*, \\ Chintha Venkataramaiah ${ }^{3}$ K. Swetha Kumari ${ }^{4}$, \\ Mavallur Varalakshmi ${ }^{5}$ and Chamarthi Naga Raju ${ }^{\circ} 1$
}

\author{
${ }^{I}$ Department of Chemistry, Sri Venkateswara University, Tirupati - 517 502, Andhra Pradesh, India. \\ ${ }^{2}$ Department of Science and Humanities, Sri Venkateswara Engineering College, Karakambadi Road, \\ Tirupati, Andhra Pradesh 517507, India \\ ${ }^{3}$ Department of Botany, Sri Venkateswara University, Tirupati - 517 502, Andhra Pradesh, India. \\ ${ }^{4}$ Department of Biosciences and Sericulture, Sri Padmavati Mahila Visvavidyalayam, Tirupati-517 \\ 502,Andhra Pradesh, India \\ ${ }^{5}$ Center for Applied Sciences, Sree Vidyanikethan Engineering College, A. Rangampet, Tirupati, \\ 517502, Andhra Pradesh, India
}

(Received November 09, 2021; Revised December 08, 2021; Accepted December 16, 2021)

\begin{abstract}
A pioneering class of urea/thiourea derivatives of naphthalene-1,5-diamine was synthesized in excellent yields $(89-96 \%)$ by one-pot procedure via treatments with phenyl isocyanates or phenyl isothiocyanates. All the constructed derivatives were evaluated for antimicrobial activity using in vitro and in silico methods. The obtained results showed that, all the titled compounds displayed the most significant antibacterial activity against gram-positive and gram-negative bacteria namely $B$. substilis, $B$. sphaerius, $S$. aureus, $P$. aeruginosa, $K$. aerogenes, $C$. violaceum and antifungal activity against A.Niger, C. tropicum, R. oryzae, F. moniliforme and C. lunata when compared with the standard drugs such as ciproflaxacin and clotrimazole. Among all, the compounds $\mathbf{2 c}, \mathbf{2 e}$ and $\mathbf{3 d}, \mathbf{3 e}$ displayed higher content of antimicrobial activity akin to the rest of the compounds due to the presence of fluoro substitution on aromatic ring. Furthermore, molecular docking studies provided support to the in vitro studies. Four of the synthesized compounds, 4-fluorophenyl, 3-trifluoromethylphenyl, 4-chlorophenyl exhibited significant binding modes and were the best target ligands as they fitted more stably into the DNA gyrase binding pocket. Henceforth, it is suggested that, the fabricated urea/thiourea derivatives of naphthalene-1,5-diamine would stand as the prosperous antimicrobial drug candidates for further studies.
\end{abstract}

Keywords: Naphthalene-1,5-diamine; antimicrobial activity; DNA Gyrases; urea/thiourea derivatives. (C2021 ACG Publication. All right reserved.

\section{Introduction}

Urea and thiourea derivatives play a significant role in the uptake of nitrogen-containing analogues and besides they are the main constituent in the urine living thing. Urea is an internal product of amino acid and protein catabolism. They is produced from ammonia, which is a de-amination compound of amino acids. Every day nearly, $20-35 \mathrm{gm}$ of urea is emitted from human urine. Urea is the earliest carbon-based compound was constructed from mineral substances by Friedrich Wohler. ${ }^{1}$ In the

${ }^{*}$ Corresponding author: E-Mail: reddinaidu.svu@gmail.com 
Venkatramana et al., Org. Commun. (2021) 14:4 323-333

literature, various researchers synthesized aromatic (Monophenyl, Diphenyl) and heterocyclic urea derivatives across the globe with potential biological applications. ${ }^{2}$ Urea derivatives show good biological activities such as antimicrobial, anticancer ${ }^{3}$ and act as anaplastic lymphoma kinase (ALK) inhibitors. ${ }^{[4]}$ These derivatives also show a broad spectrum of biological activities such as antifungal, antiviral, anticonvulsant, analgesic and HDL elevating activities. ${ }^{5-10}$

The aryl and bis-aryl urea derivatives are one of the modest substances are used in clinics. Triclocarban is primarily used in cleaning as sterilizing solutions in primary health care centers, houses, face paint, dolls, cloths and plastics as it restricts the activity of ENR (enoyl-acyl carrier-protein redutase), an enzyme to develop the cell wall of the microorganisms and fungus. ${ }^{11}$ Thiourea derivatives are essential Sulphur and nitrogen-containing mixtures these are evidenced useful constituents in drug examination in recent years. ${ }^{12-17}$ Some urea derivatives have appreciated antibacterial. Antituberculosis, and anticonvulsant activities. ${ }^{18,19}$ Majority of these derivatives consist of heterocyclic rings such as thiadiazoles, oxadiazoles, pyrazoles and triazoles. It is well-known that 1,2,4-triazole-derived N-bridged heterocycles finding applications in the area of cultivation medicine, and industry.

It was predicted that, these two energetic pharmacophores, associated together, would produce unique molecular patterns which are prospective to display promising pharmaceutical activities in animal models. In our ongoing studies are based on the various heterocyclic compounds which possess antimicrobial activity. ${ }^{20-23}$ These results are encouraged us to construction of a novel sequence of mixtures and to conduct antimicrobial tests using in vitro and in silico methodologies. To the finest of our knowledge, this is the primary explanation to deliberate the preparation and bioactive properties of naphthalene-1,5-diamine urea/thiourea derivatives.

DNA gyrase is an important bacterial enzyme that catalyses the ATP-dependent -Ve supercoiling of double-stranded closed-circular DNA. Gyrase is a class of enzymes well-known as topoisomerases that are involved in the regulator of topological changes of DNA. The mechanism by which gyrase is able to effect the topological state of DNA grains is of typical attention from an enzymological perspective. Furthermore, considerable consideration has been focused on DNA gyrase as the intracellular target of a number of antibacterial agents and as an example for other DNA topoisomerases.

Therefore, in addition to synthesis and biological evaluation studies we performed docking studies of the synthesized compounds on DNA gyrase.

\section{Experimental}

\subsection{General}

Melting points were determined using a Cintex melting point apparatus and were uncorrected. Thin-layer chromatography (TLC) was performed by using Merck silica gel 60 F254 precoated plates $(0.25 \mathrm{~mm})$. Column chromatography was performed by using Silica gel (particle size 100-200 mesh). IR spectra $(\mathrm{KBr})$ were recorded on a Perkin-Elmer BX series FTIR spectrometer. ${ }^{1} \mathrm{H}$ NMR spectra were recorded on a Bruker AMX $400 \mathrm{MHz}$ spectrometer. ${ }^{13} \mathrm{C}$ NMR spectra were recorded at operating frequency of $100 \mathrm{MHz}$ Chemical shift values are given in ppm $(\delta)$ With TMS as an internal standard. Mass spectra were determined on Agilent LC-1100 (LC-MS) series instrument. Elemental analyses were performed on a Carlo Erba 106 and Perkin Elmer model 240 analyzers. All the chemicals and reagents used in present investigation were purchased from Sigma-Aldrich.

\subsection{Chemistry}

\subsubsection{Synthesis of Urea Derivatives of Naphthalene-1,5-diamine (22a-f \& 23a-e)}

Naphthalene-1,5-diamine (1.0 eq, $0.001 \mathrm{~mol})$ and aryl-isocyanate $(2.2 \mathrm{eq}, 0.0025 \mathrm{~mol})$ were dissolved in $10 \mathrm{~mL}$ of tetrahydrofuran (THF). N, N-dimethyl-piperazine (DMPi, $0.002 \mathrm{~mol}$ ) was added at room temperature. The reaction mixture was heated to $50-55^{\circ} \mathrm{C}$ and kept for stirring for $2.5-3 \mathrm{hrs}$. Reaction progress was monitored by TLC using ethyl acetate: heptane (3:2) as a mobile phase. After completion of reaction, the reaction mixture was concentrated to residual level under reduced pressure in a rota evaporator and the crude product was purified by using ethyl acetate: diethyl ether (1:4) to 
Novel naphthalene-1,5-diamine containing urea/thiourea derivatives

obtain pure title compounds in $85-92 \%$ yield. All title compounds were synthesized by adopting the same procedure. The structures of newly synthesized urea/ thiourea derivatives $\mathbf{2 a}-\mathbf{f}$ and 3a-e were confirmed by spectral (IR, ${ }^{1} \mathrm{H},{ }^{13} \mathrm{C}$ NMR \& MS) and analytical data.

\subsubsection{Spectral Data for Constructed Derivatives}

1,1'-(Naphthalene-1,5-diyl)bis(3-(3-(trifluoromethyl)phenyl)urea)(2a): Yield: 90\%, White solid, M.P.: 221-223 ${ }^{\circ} \mathrm{C}$; IR (KBr) $v_{\max }\left(\mathrm{cm}^{-1}\right): 3286,1749,1640,1564,1423,1331,1119,904 ;{ }^{1} \mathrm{H}$ NMR $(400 \mathrm{MHz}$, DMSO- $\left.d_{6}\right): \delta 9.46(\mathrm{~s}, 2 \mathrm{H}, \mathrm{NH}), 8.92(\mathrm{~s}, 2 \mathrm{H}, \mathrm{NH}), 8.10(\mathrm{~s}, 2 \mathrm{H}, \mathrm{Ar}-\mathrm{H}), 8.02-8.04(\mathrm{~d}, 2 \mathrm{H}, J=8 \mathrm{~Hz}, \mathrm{Ar}-\mathrm{H})$, 7.89-7.91 (d, 2H, J=8 Hz, Ar-H), 7.55-7.63 (m, 6H, Ar-H), 7.33-7.34 (m, 2H, Ar-H) ${ }^{13} \mathrm{C}$ NMR $(100$ MHz, DMSO- $\left.d_{6}\right): \delta 153.4(\mathrm{C}=\mathrm{O}), 141.0,134.9,130.4,127.1,126.11\left(\mathrm{CF}_{3}\right), 125.8,125.4,122.8,118.8$, 118.58, 114.54; HR-MS: $m / z 533.142[\mathrm{M}+\mathrm{H}]^{+}$. Anal. Calcd for $\mathrm{C}_{26} \mathrm{H}_{18} \mathrm{~F}_{6} \mathrm{~N}_{4} \mathrm{O}_{2}: \mathrm{C} 58.65 \%, \mathrm{H} 3.41 \%, \mathrm{~N}$ $10.52 \%$. Found: C $58.78 \%$, H $3.43 \%$, N $10.57 \%$.

1,1'-(Naphthalene-1,5-diyl)bis(3-(3-chlorophenyl)urea) (2b): Yield: 87\%, Off white powder, M.P.:175$179^{\circ} \mathrm{C}$. IR (KBr) $v_{\max }\left(\mathrm{cm}^{-1}\right): 3252,3120,2957,1725,1638,1558,1426,1327,1129,898 ;{ }^{1} \mathrm{H}$ NMR $(400$ MHz, DMSO- $d_{6}$ ): $\delta 9.38$ (s, 2H, NH), 8.94 (s, 2H, NH), 8.08 (s, 2H, Ar-H), 7.99-8.01(d, 2H, J=8 Hz, Ar-H), 7.86-7.88 (d, 2H, J=8 Hz, Ar-H), 7.53-7.62 (m, 6H, Ar-H), 7.31-7.34(m, 2H, Ar-H); ${ }^{13} \mathrm{C}$ NMR (100 MHz, DMSO- $\left.d_{6}\right): \delta 153.5(\mathrm{C}=\mathrm{O}), 141.4,135.2,130.4$ (Ar-C-Cl), 127.4, 126.2, 125.8, 125.4, 121.8, 119, 118.6, 114; LC-MS: $m / z$ 466.0[M+H] $]^{+}, 467.0[\mathrm{M}+2]^{+}$; Anal. Calcd for $\mathrm{C}_{24} \mathrm{H}_{18} \mathrm{Cl}_{2} \mathrm{~N}_{4} \mathrm{O}_{2}: \mathrm{C} 61.95 \%$, H $3.90 \%$, N $12.04 \%$. Found: C 62.62\%, H $3.92 \%$, N $12.08 \%$.

1,1'-(Naphthalene-1,5-diyl)bis(3-(2,4-difluorophenyl)urea) (2c): Yield: 91\%, White crystalline powder, Melting range: $254-256^{\circ} \mathrm{C}$. IR $(\mathrm{KBr}) v_{\max }\left(\mathrm{cm}^{-1}\right): 3294,3075,2984,1746,1640,1562,1502,1423,1207$, 1102, 963, 849; ${ }^{1} \mathrm{H}$ NMR (400 MHz, DMSO- $\left.d_{6}\right): \delta 9.16$ (s, 2H, NH), 9.06 (s, 2H, NH), 7.92-7.95 (d, $2 \mathrm{H}, J=12 \mathrm{~Hz}$ ) Ar-H), 7.53-7.64(m, 2H, Ar-H), 7.39-7.42 (m, 2H, Ar-H), 7.34-7.37 (m, 6H, Ar-H), 7.127.15(m 2H, Ar-H); ${ }^{13} \mathrm{C}$ NMR (100 MHz, DMSO- $\left.d_{6}\right): \delta 163.9$ (Ar-F), 160.5 (Ar-F-para), 153.5 (C=O), 141.4, 134.2, 130.4, 127.5, 126.1, 125.5, 122.2,118.6, 114.5; LC-MS: $m / z$ 469.0[M+H] $]^{+}$. Anal. Calcd for $\mathrm{C}_{24} \mathrm{H}_{16} \mathrm{~F}_{4} \mathrm{~N}_{4} \mathrm{O}_{2}$ : C 61.54\%, H 3.44\%, N 11.96\%. Found: C 61.65\%, H 3.46\%, N $11.99 \%$.

1,1'-(Naphthalene-1,5-diyl)bis(3-(4-fluorophenyl)urea) (2d): Yield: 85\%, White crystalline solid, M.P.:191-193ㄷ․ IR (KBr) $v_{\max }\left(\mathrm{cm}^{-1}\right): 3274,3130,2985,1735,1628,1548,1426,1327,1129,898 ;{ }^{1} \mathrm{H}$ NMR (400 MHz, DMSO- $\left.d_{6}\right): \delta 9.38$ (s, $\left.2 \mathrm{H}, \mathrm{NH}\right), 8.94(\mathrm{~s}, 2 \mathrm{H}, \mathrm{NH}), 8.02-8.04(\mathrm{~d}, 2 \mathrm{H}, \mathrm{Ar}-\mathrm{H})$, 7.98(d, 2H, J=16Hz, Ar-H), 7.75-7.79 (m, 2H, Ar-H), 7.53-7.60 (m, 6H, Ar-H), 7.21-7.24(d, 2H, Ar$\mathrm{H}) ;{ }^{13} \mathrm{C}$ NMR (100 MHz, DMSO- $\left.d_{6}\right): \delta 162.5$ (Ar-F), 153.7, 141.6, 135.5, 130.7, 128, 125.4, 121.8, 119, 105.3; LC-MS: $m / z$ 433.2[M+H] $]^{+}$. Anal. Calcd for $\mathrm{C}_{24} \mathrm{H}_{18} \mathrm{~F}_{2} \mathrm{~N}_{4} \mathrm{O}: \mathrm{C} 66.66 \%, \mathrm{H} 4.20 \%, \mathrm{~N} 12.96 \%$. Found: C $66.62 \%, \mathrm{H} 4.22 \%$, N $12.99 \%$.

1,1'-(Naphthalene-1,5-diyl)bis(3-(4-chloro-3-(trifluoromethyl)phenyl)urea) (2e): Yield: 92\%, White crystalline powder, M.P.: $241-245^{\circ} \mathrm{C}$. IR $(\mathrm{KBr}) v_{\max }\left(\mathrm{cm}^{-1}\right): 3337,3150,3127,3112,2975,1634,1592$, 1534, 1518, 1420, 843; ${ }^{1} \mathrm{H}$ NMR (400 MHz, DMSO- $\left.d_{6}\right): \delta 9.38$ (s, 2H, NH), $8.94(\mathrm{~s}, 2 \mathrm{H}, \mathrm{NH}), 8.08$ (s, 2H, Ar-H), 7.97-7.99 (d, 2H, $J=8 \mathrm{~Hz}, \mathrm{Ar}-\mathrm{H}), 7.73-7.75(\mathrm{~d}, 2 \mathrm{H}, J=8 \mathrm{~Hz}$ Ar-H), 7.52-7.59 (m, $6 \mathrm{H}, \mathrm{Ar}-\mathrm{H})$, 7.25-7.28(m, 2H, Ar-H) $;{ }^{13} \mathrm{C}$ NMR (100 MHz, DMSO- $\left.d_{6}\right): \delta 153.6(\mathrm{C}=\mathrm{O}), 145.3,140.2,134.9$, 130.4(Ar-Cl), 127.1, 126.11,125.8, $125.4\left(\mathrm{CF}_{3}\right), 122.8,118.58,114.54$; LC-MS: $m / z$ 602.2[M+H] ${ }^{+}$.Anal. Calcd for $\mathrm{C}_{26} \mathrm{H}_{16} \mathrm{Cl}_{2} \mathrm{~F}_{6} \mathrm{~N}_{4} \mathrm{O}_{2}$ : C 51.93\%, H 2.68\%, N 9.32\%. Found: C 52.04\%, H 2.71\%, N 9.35\%.

1,1'-(Naphthalene-1,5-diyl)bis(3-(4-bromophenyl)urea)(2f): Yield: 85\%, Pale brown color solid, M.P.: $224-225^{\circ} \mathrm{C}$. IR (KBr) $v_{\max }\left(\mathrm{cm}^{-1}\right): 3254,3110,2977,1735,1627,1548,1416,1337,1139,823 ;{ }^{1} \mathrm{H}$ NMR $\left(400 \mathrm{MHz}, \mathrm{DMSO}-d_{6}\right): \delta 9.32$ (s, 2H, NH), 8.96 (s, 2H, NH), 8.03-8.05 (d, 2H, $\left.J=8 \mathrm{~Hz}, \mathrm{Ar}-\mathrm{H}\right), 7.96-$ 7.99(m, 2H, Ar-H), 7.77-7.79 (d, 2H, J=8Hz, Ar-H), 7.54-7.61 (m, 6H, Ar-H), 7.22-7.25(d, 2H, Ar-H); ${ }^{13} \mathrm{C}$ NMR $\left(100 \mathrm{MHz}\right.$, DMSO- $\left.d_{6}\right)$ : $\delta 153.6(\mathrm{C}=\mathrm{O}), 141.5,135.4,130.9,127.8,126.5,123.25(\mathrm{Ar}-\mathrm{Br})$, 120.8, 117.5, 105.8; LC-MS: $m / z$ 555.25 [M+H] $]^{+}, 556.3[\mathrm{M}+2]^{+}$. Anal. Calcd for $\mathrm{C}_{24} \mathrm{H}_{18} \mathrm{Br}_{2} \mathrm{~N}_{4} \mathrm{O}_{2}: \mathrm{C}$ $52.01 \%$, H 3.27\%, N 10.11\%. Found: C 52.14\%, H 3.29\%, N $10.13 \%$. 
1,1'-(Naphthalene-1,5-diyl)bis(3-phenylthiourea) (3a):Yield: 89\%, Off white solid, M.P.:222-224 ${ }^{\circ} \mathrm{C}$. IR $(\mathrm{KBr}) v_{\max }\left(\mathrm{cm}^{-1}\right): 3336,3164,2958,1597.6,1531,1416,1223,1156,786.6 ;{ }^{1} \mathrm{H}$ NMR $(400 \mathrm{MHz}$, DMSO- $\left.d_{6}\right): \delta 9.91$ (brs, $\left.2 \mathrm{H}, \mathrm{NH}\right), 7.93(\mathrm{brs}, 2 \mathrm{H}, \mathrm{NH}), \quad 7.89-7.91(\mathrm{~d}, 4 \mathrm{H}, J=8 \mathrm{~Hz}, \mathrm{Ar}-\mathrm{H}) ; 7.77-7.79(\mathrm{~d}$, $4 \mathrm{H}, J=12 \mathrm{~Hz}$ Ar-H), 7.45-7.51 (m, 6H, Ar-H); 7.26-7.29 (m, 2H, Ar-H) ${ }^{13} \mathrm{C}$ NMR (100 MHz, DMSO$\left.d_{6}\right): \delta 181.5(\mathrm{C}=\mathrm{S}), 141.6,141.2,136.03,131.39,129.4,126.16,122.4 ; \mathrm{LC}-\mathrm{MS}: \mathrm{m} / z$ 429.5[M+H] ${ }^{+}$.Anal. Calcd for $\mathrm{C}_{24} \mathrm{H}_{20} \mathrm{~N}_{4} \mathrm{~S}_{2}$ : C 67.26\%, H 4.70\%, N 13.07\%; Found: C 67.38\%, H 4.74\%, N $13.14 \%$.

1,1'-(Naphthalene-1,5-diyl)bis(3-(4-nitrophenyl)thiourea) (3b):Yield: 91\%, Pale yellow color solid, M.P.: 234-236 ${ }^{\circ} \mathrm{C}$. IR (KBr) $v_{\max }\left(\mathrm{cm}^{-1}\right): 3347,3160,2957.9,1595.7,1535,1422,1224,1036,786.6 ;{ }^{1} \mathrm{H}$ NMR (400 MHz, DMSO- $d_{6}$ ): $\delta 9.88$ (brs, 2H, NH), 7.91 (brs, 2H, NH), 7.16-7.18 (d, 4H, J=8Hz, Ar$\mathrm{H})$, 7.29-7.36 (m, 6H, Ar-H), 7.13-7.16 (m, 4H, Ar-H); ${ }^{13} \mathrm{C}$ NMR (100 MHz, DMSO- $\left.d_{6}\right): \delta 181.7(\mathrm{C}=\mathrm{S})$, 145.9, 141.1, 136, 131.4, 129.7, 126.2, 122.4, 116.2, 109.7; LC-MS: $m / z$ 519.2 [M+H] ${ }^{+}$. Anal. Calcd for $\mathrm{C}_{24} \mathrm{H}_{18} \mathrm{~N}_{6} \mathrm{O}_{4} \mathrm{~S}_{2}: \mathrm{C} 55.59 \%, \mathrm{H} 3.50 \%, \mathrm{~N} 16.21 \%$; Found: C 55.63\%, H 3.55\%, N 16.25\%.

1,1'-(Naphthalene-1,5-diyl)bis(3-(2,6-difluorophenyl)thiourea) (3c):Yield: 90\%, White crystal Solid, M.P.: $227-230^{\circ} \mathrm{C}$. IR (KBr) $v_{\max }\left(\mathrm{cm}^{-1}\right): 3294,3075,2977,1746,1640,1562,1502,1423,1324,1102$, 963, 786; ${ }^{1} \mathrm{H}$ NMR (400 MHz, DMSO- $\left.d_{6}\right): \delta 10.26(\mathrm{~s}, 2 \mathrm{H}, \mathrm{NH}), 9.16(\mathrm{~s}, 2 \mathrm{H}, \mathrm{NH}), 7.53-7.55(\mathrm{~d}, 2 \mathrm{H}$, $J=8 \mathrm{~Hz}, \mathrm{Ar}-\mathrm{H}), 7.53-7.64(\mathrm{~m}, 4 \mathrm{H}, \mathrm{Ar}-\mathrm{H}), 7.32-7.42(\mathrm{~m}, 2 \mathrm{H}, \mathrm{Ar}-\mathrm{H}), 7.12-7.17$ (m, 4H, Ar-H); ${ }^{13} \mathrm{C}$ NMR $\left(100 \mathrm{MHz}, \mathrm{DMSO}-d_{6}\right): \delta 180.9(\mathrm{C}=\mathrm{S}), 169.4$ (Ar-CF) $141.1,134.9,130.5,127.5,122.2,118.8,117.4$, 114.5; LC-MS: $m / z 501.48[\mathrm{M}+\mathrm{H}]^{+}, 502.51[\mathrm{M}+2]^{+}$. Anal. Calcd for $\mathrm{C}_{24} \mathrm{H}_{16} \mathrm{~F}_{4} \mathrm{~N}_{4} \mathrm{~S}_{2}$ : C 57.59\%, H 3.22\%, N 11.19\%.; Found: C 57.69\%, H 3.24\%, N 11.23\%.

1,1'-(Naphthalene-1,5-diyl)bis(3-(3,4-dichlorophenyl)thiourea) (3d):Yield: 89\%, Off white powder, M.P.: $247-248^{\circ} \mathrm{C}$. IR (KBr) $v_{\max }\left(\mathrm{cm}^{-1}\right): 3289,3086,2977,1736,1635,1548,1512,1433,1311,1196$, 963, 823, 795; ${ }^{1} \mathrm{H}$ NMR (400 MHz, DMSO- $d_{6}$ ): $\delta 3.73$ (brs, 4H, NH), 7.85-7.98 (m, 4H, Ar-H), 7.50$7.61(\mathrm{~m}, 8 \mathrm{H}, \mathrm{Ar}-\mathrm{H}) ;{ }^{13} \mathrm{C}$ NMR $\left(100 \mathrm{MHz}\right.$, DMSO- $\left.d_{6}\right): \delta 181.4,141.1,140.3,136.5,131.2,129.6,126.2$, 122.5, 116.3, 110.5, 109.6; LC-MS: $m / z$ 567.1[M+H] ${ }^{+}$. Anal. Calcd for $\mathrm{C}_{24} \mathrm{H}_{16} \mathrm{Cl}_{4} \mathrm{~N}_{4} \mathrm{~S}_{2}: \mathrm{C} 50.90 \%, \mathrm{H}$ $2.85 \%$, N 9.89\%: Found: C 50.98\%, H 2.87\%, N $9.99 \%$.

1,1'-(Naphthalene-1,5-diyl)bis(3-(m-tolyl)thiourea) (3e):Yield: 92\%, Off white solid, M.P.:135-137 ${ }^{\circ} \mathrm{C}$. IR (KBr) $v_{\max }\left(\mathrm{cm}^{-1}\right): 3336,3164,2958,1597,1531,1416,1223,1156,1036,786 ;{ }^{1} \mathrm{H}$ NMR $(400 \mathrm{MHz}$, DMSO- $\left.d_{6}\right): \delta 9.46(\mathrm{~s}, 2 \mathrm{H}, \mathrm{NH}), 8.92(\mathrm{~s}, 2 \mathrm{H}, \mathrm{NH}), 8.10(\mathrm{~s}, 2 \mathrm{H}, \mathrm{Ar}-\mathrm{H}), 8.02-8.04(\mathrm{~d}, 2 \mathrm{H}, J=8 \mathrm{~Hz}, \mathrm{Ar}-\mathrm{H})$, 7.89-7.91 (d, 2H, $J=8 \mathrm{~Hz}, \mathrm{Ar}-\mathrm{H}), 7.55-7.63(\mathrm{~m}, 6 \mathrm{H}, \mathrm{Ar}-\mathrm{H}), 7.33-7.34$ (quasi d, $2 \mathrm{H}, J=4 \mathrm{~Hz}, \mathrm{Ar}-\mathrm{H}) ; 3.76$ (s, 6H, Ar-H) ${ }^{13} \mathrm{C}$ NMR (100 MHz, DMSO- $\left.d_{6}\right): \delta 181.6(\mathrm{C}=\mathrm{S}) 141.1,136,131.4,129.7,126.2,122.4$, 116.2, 109.8, 55.55; LC-MS: $m / z$ 457.3[M+H] $]^{+}$. Anal. Calcd for $\mathrm{C}_{26} \mathrm{H}_{24} \mathrm{~N}_{4} \mathrm{~S}_{2}: \mathrm{C} 68.39 \%, \mathrm{H} 5.30 \%, \mathrm{~N}$ 12.27\%. Found: C $68.52 \%$, H 5.34\%, N $12.32 \%$.

\subsection{Biological Assay}

\subsubsection{Antibacterial Activity}

The newly prepared compounds were studied in vitro for antibacterial activity against the growth of Gram-negative bacteria namely Pseudomonas aeruginosa, Klebsiella aerogenes, Chromobacterium violaceum and Gram-positive bacteria namely Bacillus subtilis, Bacillus sphaericus and Staphylococcus aureus at $100 \mu \mathrm{g} / \mathrm{mL}$ concentration by using agar well diffusion method. Ciprofloxacin was used as the standard. ${ }^{24}$ The obtained results are summarized in Table1.

\subsubsection{Antifungal Activity}

Antifungal activities of 2a-f and 3a-e were determined by using the agar cup bioassay method ${ }^{25}$ with Clotrimazole as the standard. The compounds were tested for their antifungal activity against five test organisms namely Aspergillus niger, Chrysosporium tropicum, Rhizopus oryzae, Fusarium 
Novel naphthalene-1,5-diamine containing urea/thiourea derivatives

moniliforme and Curvularia lunata using the agar cup bioassay method at $100 \mu \mathrm{g} / \mathrm{mL}$ concentration. The nutrient broth medium (HiMedia, $40 \mathrm{~g}$ ) was suspended in distilled water $(1000 \mathrm{~mL}$ ) and heated until it was dissolved completely. The medium and Petri dishes were autoclaved at a pressure of $15 \mathrm{lb} / \mathrm{inc}$ for $20 \mathrm{~min}$. The medium was poured into sterile Petri dishes under aseptic conditions in a laminar flow chamber. After media solidification, $0.5 \mathrm{~mL}$ culture of the test organism was inoculated by uniform spreading over the agar surface with a sterile L-shaped rod. Solutions were prepared by dissolving plant extract in dimethyl sulfoxide (DMSO) at a concentration of $100 \mu \mathrm{g} / \mathrm{mL}$. Agar inoculation cups were scooped out with a $6 \mathrm{~mm}$ sterile cork borer and the lids of the dishes were replaced. To each cup, 100 $\mu \mathrm{g} / \mathrm{mL}$ of the test solution was added. Controls were maintained with DMSO and Clotrimazole (100 $\mu \mathrm{g} / \mathrm{mL}$ ). The treated and controls were kept at RT for 72-95 h. Inhibition zones were determined by measuring the diameter in millimeter. The obtain results are presented in Table 2.

\subsubsection{Molecular Docking Analysis}

Streptomycin is an aminoglycoside antibiotic resulting from Streptomyces griseus having antibacterial activity. Streptomycin irreversibly binds to the 16S ribosomal RNA and S12 protein which are within $30 \mathrm{~S}$ ribosomal subunit of bacteria. As a result, this agent inhibits with the assembly of initiation composite between mRNA and the bacterial ribosome, thereby preventing the beginning of protein construction. In addition, streptomycin gives misinterpretation of the mRNA pattern and causes translational frameshift, thereby resulting in premature termination followed by bacterial cell death.

Docking studies were voted for between DNA Gyrase A protein and the selected targets 2a-f $\boldsymbol{\&}$ 3a-e and the backing drug Streptomycin 1, using the docking segment executed in Pyrx2010.12. At first, the protein constructions were protonated with the addition of polar hydrogens, monitored by energy minimization with the MMFF94x force field, in order to get the constant conformer of the protein. Springy docking was carried, the inhibitor binding site was decreased and moderated, emphasized through the "Site Finder" module applied in the Pymol software. The network sizes were anticipated as ${ }^{\circ} \mathrm{X}: 28.27, \mathrm{Y}: 27.13, \mathrm{Z}: 28.51$ for Aromatase correspondingly. The docking was performed with factors i.e., placement: triangle matcher, recording 1: London dG, refinement: force field. All-out of 10 conformations of each target were permitted to be saved in a distinct database file in .mdb arrangement. After the docking method, the binding affinity and binding energy of the protein-ligand developments were calculated using Pymol viewer tool (www.pymol.org).

\section{Results and Discussion}

\subsection{Chemistry}

The title bis-urea derivatives 2a-f and 3a-e were fabricated by modest addition reaction of functionalized Naphthalene-1,5-diamine with aryl-isocyanates and aryl-isothio cyanates in presence of 1,4-dimethyl piperazine (DMPiz). The schematic representation is presented in Figure 1. The products were cleaned by column chromatography using Ethyl acetate: diethyl ether (3:2) to obtain pure title compounds in $85-92 \%$ yield. All the products were synthesized by adopting the same procedure. The structures of newly synthesized urea derivatives $2 \mathbf{a}-\mathbf{f}$ and 3a-e were identified by spectral $\left(\mathrm{IR},{ }^{1} \mathrm{H},{ }^{13} \mathrm{C}\right.$ NMR \& MS) \& analytical data. 


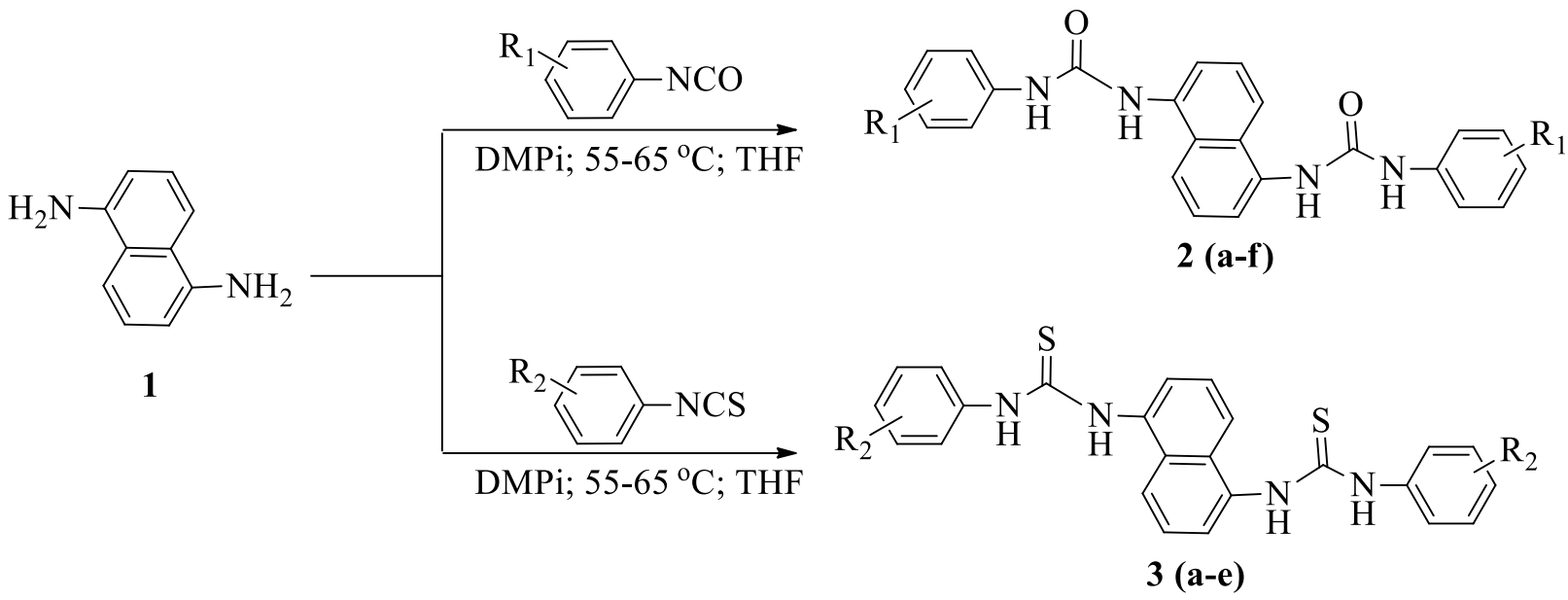

$\mathrm{R}_{1}=2 \mathrm{a}: 3-\mathrm{CF}_{3} ; 2 \mathrm{~b}: 3-\mathrm{Cl} ; 2 \mathrm{c}: 2,4-\mathrm{F} ; 2 \mathrm{~d}: 4-\mathrm{F} ; 2 \mathrm{e}: 3-\mathrm{CF}_{3}, 4-\mathrm{Cl} ; 2 \mathrm{f}: 4-\mathrm{Br}$

$\mathrm{R}_{2}=3 \mathrm{a}: \mathrm{H} ; 3 \mathrm{~b}: 4-\mathrm{NO}_{2} ; 3 \mathrm{c}: 2,6-\mathrm{F} ; 3 \mathrm{~d}: 3,4-\mathrm{Cl} ; 3 \mathrm{e}: 3-\mathrm{CH}_{3}$

Figure 1. Schematic representation of synthesis of urea/thiourea derivatives ofnaphthalene-1, 5diamine (2a-f and 3a-e)

IR spectral data were used to find out the functional groups existing in the constructed derivatives 2(a-f)/ 3(a-e) and are presented in experimental data. The absorption bands in IR spectra were obtained in the region of $3286-3336 \mathrm{~cm}^{-1}$ presence of $-\mathrm{NH}$ group, the bands appeared in the range of $1749-1640 \mathrm{~cm}^{-1}$ for $-\mathrm{C}=\mathrm{O}$ groups. Whereas the $\mathrm{C}=\mathrm{S}$ group were observed in the region of 1597 . The ${ }^{1} \mathrm{H}$ NMR spectroscopic data of compounds $2(\mathbf{a}-\mathbf{f}) / \mathbf{3}(\mathbf{a}-\mathbf{e})$ are presented in experimental part and the obtained data was agreement with the proposed structures. In ${ }^{1} \mathrm{H}$ NMR spectra, two singlet signals were appeared in between 9.46-8.96 ppm confirming the -CONH protons, a singlet signal appeared in the range of 9.91 ppm confirming the -CSNH protons, the chemical shifts in the region of 8.10-7.28 ppm were due to aromatic protons appeared as singlet, doublet and multiplet, respectively.

The ${ }^{13} \mathrm{C}$ NMR spectroscopic data of compounds $\mathbf{2}(\mathbf{a}-\mathbf{f}) / 3(\mathbf{a}-\mathbf{e})$ are presented in experimental part and the obtained data was agreement with the proposed structures. In ${ }^{13} \mathrm{C}$ NMR spectra, the peaks in the region of 159-109 ppm were assigned to carbons of aromatic ring. The signals in the region of 181 and $153 \mathrm{ppm}$ corresponds to $\mathrm{C}=\mathrm{S}$ and $\mathrm{C}=\mathrm{O}$ respectively. The mass spectrometric data of compounds 2 (af)/3(a-e) are presented in the experimental part.

\subsection{Biological Assay}

\subsubsection{Antibacterial Activity}

The antibacterial activity results for compounds 2a-f displayed decent activity. The compounds $2 \mathbf{c}$ and $2 \mathbf{e}$ containing fluoro and fluoro, chloro groups on the benzene ring exhibited high activity. The activity of the compound depends upon the position of the substituent at the phenyl group. The substituents particularly chloro, fluoro and trifluoromethyl groups attached to phenyl ring increases the activity extraordinarily. Compounds $2 \mathbf{c}$ and $\mathbf{2 e}$ shown significant activity. Among all these derivaties target $2 \mathbf{c}$ revealed activity is equivalent to that of Ciproflaxacin. However, the degree of inhibition varied both with test compound as well as bacteria used in the present investigation. In conclusion, majority of compounds 2a-f showed worthy activity by preventing growth of all the bacteria to a greater extent. These remarkable results may consider to the existence of urea is linked to aromatic ring. 
Novel naphthalene-1,5-diamine containing urea/thiourea derivatives

Table 1. Antibacterial activity data of compounds 2a-f and 3a-e as MIC ${ }^{\mathrm{a}}(\mu \mathrm{g} / \mathrm{mL})$

\begin{tabular}{lcccccc}
\hline & \multicolumn{3}{c}{ Gram-positive } & \multicolumn{3}{c}{ Gram-negative } \\
\hline Compound & B.substilis & B.sphaerius & S.aureus & P.aeruginosa & K.aerogenes & C.violaceum \\
\hline $\mathbf{2 a}$ & 22 & 24 & 24 & 32 & 24 & 30 \\
$\mathbf{2 b}$ & 21 & 24 & 21 & 28 & 25 & 26 \\
$\mathbf{2 c}$ & 18 & 21 & 18 & 21 & 23 & 25 \\
$\mathbf{2 d}$ & 24 & 25 & 30 & 35 & 26 & 28 \\
$\mathbf{2 e}$ & 20 & 22 & 18 & 27 & 22 & 25 \\
$\mathbf{2 f}$ & 24 & 25 & 30 & 29 & 26 & 28 \\
$\mathbf{3 a}$ & 23 & 27 & 20 & 37 & 26 & 25 \\
$\mathbf{3 b}$ & 21 & 25 & 24 & 31 & 24 & 22 \\
$\mathbf{3 c}$ & 21 & 20 & 17 & 30 & 23 & 26 \\
$\mathbf{3 d}$ & 23 & 24 & 25 & 27 & 24 & 24 \\
$\mathbf{3 e}$ & 21 & 22 & 19 & 27 & 22 & 25 \\
Ciproflaxacin & 20 & 25 & 20 & 30 & 25 & 25 \\
\hline
\end{tabular}

Note: ${ }^{a}$ Negative control (DMSO) - No activity

\subsubsection{Antifungal Activity}

The antifungal activity results revealed that, compounds 2a-f and 3a-e are potential toxic towards all the five fungi and they are lethal even at $100 \mu \mathrm{g} / \mathrm{mL}$ concentration. In series $\mathbf{2}$, targets $\mathbf{2 c}$ and $2 \mathrm{e}$ showed high antifungal activity owing to the presence of trifloromethyl, fluoro, chloro and bromo groups are present on the aromatic ring. In series $\mathbf{3}$, targets $\mathbf{3 d}$ and $\mathbf{3 e}$ showed good antifungal activity owing to the fluoro, chloro, difluro and methyl groups are present on benzene ring. The obtained results compared with the standard drug clotrimazole revealed their promising activities. In conclusion, all the series of compounds $\mathbf{2 a - f}$ and 3a-e are moderately lethal towards the fungi under examination and they are lethal even at $100 \mu \mathrm{g} / \mathrm{mL}$ concentration in comparison with standard Clotrimazole at the same concentration.

Table 2. Antifungal activity screening data of compounds $\mathbf{2 a - f}$ and 3a-e as $\mathrm{MIC}^{\mathrm{a}, \mathrm{b}}(\mu \mathrm{g} / \mathrm{mL})$

\begin{tabular}{cccccc}
\hline Compound & A.niger & C. tropicum & R. oryzae & F. moniliformae & C. lunata \\
\hline $\mathbf{2 a}$ & 24 & 25 & 18 & 19 & 20 \\
$\mathbf{2 b}$ & 23 & 28 & 14 & 17 & 23 \\
$\mathbf{2 c}$ & 29 & 29 & 23 & 21 & 27 \\
$\mathbf{2 d}$ & 27 & 24 & 21 & 18 & 25 \\
$\mathbf{2 e}$ & 30 & 28 & 24 & 19 & 29 \\
$\mathbf{2 f}$ & 28 & 26 & 21 & 19 & 20 \\
$\mathbf{3 a}$ & 24 & 22 & 17 & 14 & 18 \\
$\mathbf{3 b}$ & 23 & 25 & 14 & 17 & 22 \\
$\mathbf{3 c}$ & 26 & 21 & 21 & 19 & 21 \\
$\mathbf{3 d}$ & 24 & 25 & 22 & 19 & 25 \\
$\mathbf{3 e}$ & 30 & 28 & 24 & 19 & 29 \\
Clotrimazole & 30 & 29 & 23 & 20 & 28 \\
\hline
\end{tabular}

Note: ${ }^{a}$ Negative control (DMSO)-no activity; ${ }^{\mathrm{b}}$ Concentration $100 \mu \mathrm{g} / \mathrm{mL}$. 
Venkatramana et al., Org. Commun. (2021) 14:4 323-333

\subsubsection{Molecular Docking Analysis}

In order to get some information about the possible uses of synthesized compounds, docking study was carried out for targets (2a-f and 3a-e) with particular pharmacological target such as DNA Gyrase A protein of $E$. coli which is appropriate target for anti-bacterial activity.

Table 3. Docking analysis of synthesized compounds (2a-f and 3a-e) and streptomycin (standard) against E. coli DNA Gyrase A protein

\begin{tabular}{|c|c|c|c|c|c|c|}
\hline $\begin{array}{l}\text { Sl } \\
\text { No } \\
\end{array}$ & Compound & $\begin{array}{l}\text { Binding } \\
\text { Energy }\end{array}$ & $\begin{array}{c}\text { Binding } \\
\text { interaction }\end{array}$ & $\begin{array}{c}\text { Bond Length } \\
\left(\mathbf{A}^{\mathbf{O}}\right)\end{array}$ & $\begin{array}{c}\text { Bond } \\
\text { Angle }\left({ }^{\circ}\right)\end{array}$ & $\begin{array}{l}\text { Bond } \\
\text { Type } \\
\end{array}$ \\
\hline \multirow[t]{10}{*}{1} & Streptomycin & -6.9 & Asg 139 CG...HN & 2.2 & 124.4 & H- don \\
\hline & & & Leu 135 CD...HN & 2.7 & 125.7 & H- don \\
\hline & & & His $132 \mathrm{CB} \ldots \mathrm{OH}$ & 2.5 & 125.0 & H- acc \\
\hline & & & Asp 53 CG...OC & 3.4 & 116.7 & H- acc \\
\hline & & & Asp 53 OC...OC & 2.9 & 118.9 & H- acc \\
\hline & & & Asp 58 OD...OH & 2.0 & 118.6 & H- acc \\
\hline & & & Asp 58 OD...HN & 2.5 & 116.4 & H- don \\
\hline & & & His 132 ND...OC & 2.8 & 126.2 & H- acc \\
\hline & & & His 132 ND...OC & 2.7 & 120.0 & H- acc \\
\hline & & & His $132 \mathrm{OC} \ldots \mathrm{OH}$ & 2.5 & 119.8 & H- acc \\
\hline \multirow[t]{3}{*}{2} & $2 \mathbf{a}$ & -7.9 & Lys270 HZ...OC & 1.9 & 110.3 & H- acc \\
\hline & & & Lys $270 \mathrm{HZ} \ldots$. OC & 2.02 & 109.6 & H- acc \\
\hline & & & Asp 297 CA...HN & 1.8 & 122.2 & H- don \\
\hline \multirow[t]{5}{*}{3} & $2 \mathbf{b}$ & -7.9 & Gly 110 OC...HN & 1.9 & 121.7 & H- don \\
\hline & & & Gly 110 OC...HN & 2.3 & 123.1 & H- don \\
\hline & & & Asn 108 CG...HO & 2.3 & 121.5 & H- don \\
\hline & & & Phe 109 CA...OC & 2.0 & 115.1 & H- acc \\
\hline & & & Gly 110 HN...OC & 2.8 & 124.4 & $\mathrm{H}-\mathrm{acc}$ \\
\hline \multirow[t]{5}{*}{4} & $2 c$ & -7.4 & Thr 219 CA...HO & 2.0 & 119.9 & H- don \\
\hline & & & Leu 264 HN...OC & 2.2 & 114.7 & H- acc \\
\hline & & & Val 103 OC...HO & 2.0 & 124.6 & H- don \\
\hline & & & Gly 105 HN...OC & 2.2 & 124.7 & H- acc \\
\hline & & & Gly 105 OC...HN & 2.2 & 124.2 & H- don \\
\hline \multirow[t]{2}{*}{5} & $2 d$ & -8.2 & Gly 105 CA...HN & 2.0 & 124.2 & H- don \\
\hline & & & Asp 104 CG...HN & 2.4 & 118.7 & H- don \\
\hline \multirow[t]{4}{*}{6} & $2 e$ & -8.6 & Glu 263 CD...NH & 2.6 & 116.7 & H- acc \\
\hline & & & Gly 105 OC...NH & 2.3 & 121.8 & $\mathrm{H}-\mathrm{acc}$ \\
\hline & & & Gly 110 OC...HN & 1.9 & 123.1 & H- don \\
\hline & & & Gly 110 OC...HN & 2.4 & 121.7 & H- don \\
\hline 7 & $2 f$ & -9.1 & Gly 105 CA...HN & 2.3 & 124.2 & H- don \\
\hline \multirow[t]{2}{*}{8} & 3a & -8.8 & Gly 110 OC...HN & 2.0 & 123.1 & H- don \\
\hline & & & Gly 110 CA...HN & 2.3 & 121.7 & H- don \\
\hline \multirow[t]{2}{*}{9} & $\mathbf{3 b}$ & -8.6 & Gly 110 OC...HN & 2.3 & 121.7 & H- don \\
\hline & & & Met $301 \mathrm{HN} \ldots \mathrm{OC}$ & 2.1 & 122.2 & $\mathrm{H}-\mathrm{acc}$ \\
\hline \multirow[t]{2}{*}{10} & $3 c$ & -8.1 & Glu 263 CD ... NH & 2.6 & 116.7 & H- acc \\
\hline & & & Gly 110 OC...HN & 2.4 & 121.3 & H- don \\
\hline \multirow[t]{3}{*}{11} & 3d & -8.3 & Arg 518 NE...OC & 2.4 & 119.2 & H- acc \\
\hline & & & Asp 297 OC... HN & 2.6 & 121.4 & H- don \\
\hline & & & Lys 270 NZ....OC & 2.3 & 110.3 & H- acc \\
\hline \multirow[t]{2}{*}{12} & $3 \mathbf{e}$ & -8.8 & Asp 297 CA....HN & 2.0 & 122.4 & H- don \\
\hline & & & Lys 270 NZ...OC & 2.3 & 110.3 & $\mathrm{H}-\mathrm{acc}$ \\
\hline
\end{tabular}


Novel naphthalene-1,5-diamine containing urea/thiourea derivatives

The crystal structure of DNA Gyrase A (PDB id: 3LPX) was recovered from the protein data bank (PDB) and the reference drug Streptomycin (PC ID 19649) from Pub Chem Drug bank. The docking results of DNA Gyrase A showed that, compounds 2a-f and 3a-eshowed noteworthy binding modes compared to the control drug Streptomycin (-6.9). All the compounds have formed higher binding energies than the reference compound. The H-bonds, binding affinities and energy profiles of compounds 2a-f and 3a-ealong with reference drugs, the active site amino acids of the enzyme are presented in Table 3. The binding modes of compounds $\mathbf{2 f}, \mathbf{3 a}, \mathbf{3 b}$ and $\mathbf{3 e}$ are suggested as the best target ligands as that they built-in more firmly into the DNA Gyrase binding pocket (Figure 3). Therefore, the current study exhibit that the synthesized compounds are promising next generation anti-microbial drugs, which can be efficiently used in the treatment of microbial and other related contagions.

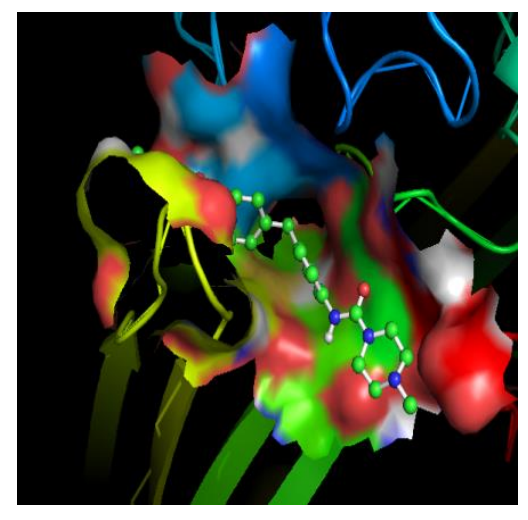

$2 \mathrm{e}$

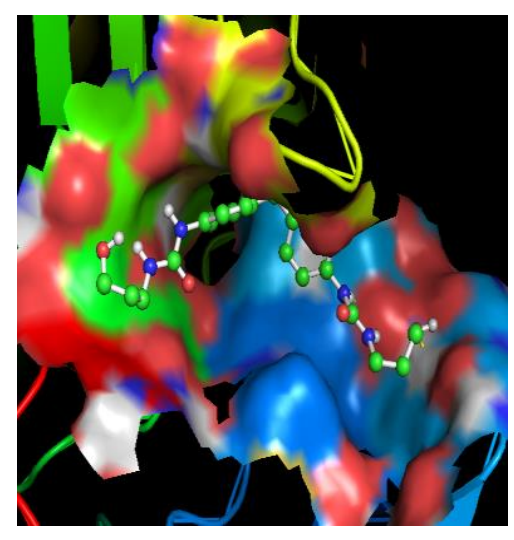

$3 b$

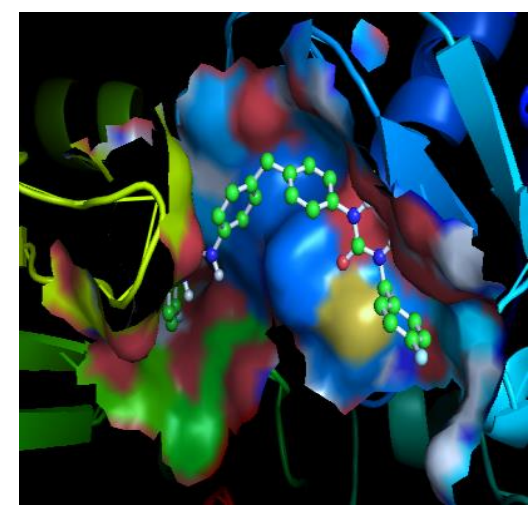

$2 \mathrm{f}$

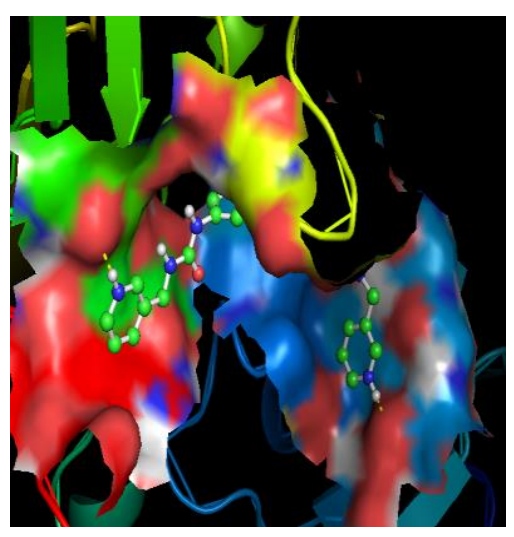

$3 e$

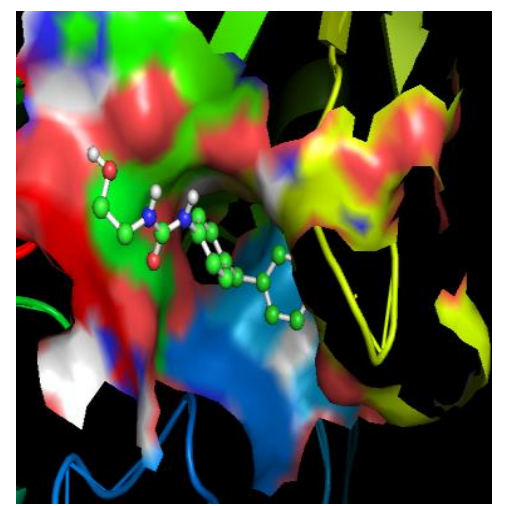

$3 \mathrm{a}$

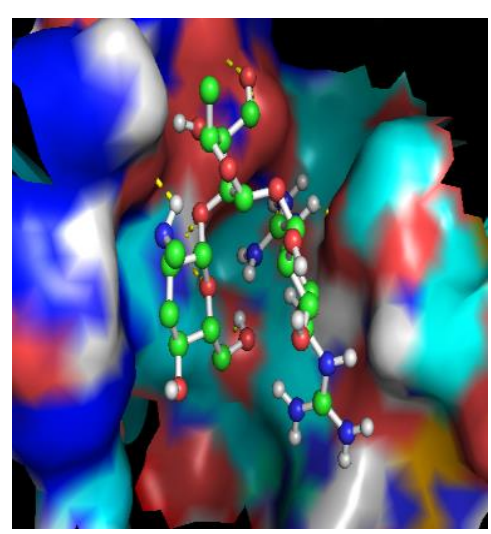

Streptomycin

Figure 2. Docking poses of selected ligands with DNA Gyrase A Protein (3LPX)

\section{Conclusion}

A simple, efficient and practical method has been developed for the synthesis of novel urea and thiourea derivatives of naphthalene-1,5-diamine 2a-f and 3a-e. In series 2, compounds $\mathbf{2 c}$ and $\mathbf{2 e}$, in series $\mathbf{3}$, compounds $\mathbf{3 d}$ and $\mathbf{3 e}$ showed high antifungal activity which may be due to the presence of fluoro, fluorochloro, trifloromethyl and methyl groups as substituents on the benzene ring. This method offers several advantages like mild reaction conditions, enhanced reaction rates, easy isolation of products and operational simplicity and compounds yields are high. 
Venkatramana et al., Org. Commun. (2021) 14:4 323-333

\section{Acknowledgements}

The authors are grateful to the management and principals of SV Colleges for their support and encouragement during the research.

\section{Supporting Information}

Supporting information accompanies this paper on http://www.acgpubs.org/journal/organic$\underline{\text { communications }}$

\section{ORCID}

Lachhireddy Venkataramana: 0000-0002-9923-8996

Reddi Mohan Naidu Kalla: 0000-0001-7689-2242

Chintha Venkataramaiah: $\underline{0000-0002-0493-6047}$

K. Swetha Kumari: 0000-0002-8316-1891

Mavallur Varalakshmi:0000-0001-6638-6813

Chamarthi Naga Raju:0000-0001-6566-2118

\section{References}

[1] Wohler F. "Ueber künstliche Bildung des Harnstoffs". Annal. der Physik Chem. 1828, 88 (2):253-256.

[2] Li, H.Q.; Lv, P.C.; Yan, T.; Zhu, H.L. Urea derivatives as anticancer agents. Anticancer. Agents. Med. Chem. 2009, 9(4), 471-80.

[3] Kumar, K. P.; Kalla, R.M.N.; Varalakshmi, M.; Venkataramaiah, C.; Kumari, K. S.; Kannali, J. Reddy D.V.; Nagaraju, C.Synthesis, spectral characterization, antimicrobial activity and docking studies against DNA Gyrase-A of new 4-chloro-3- nitrobenzene sulfonamide derivatives. Org. Commun. 2020, 13(4), 155-164.

[4] Hamby, J.M.; Groha,. P.J.; Dohetry, A.M. Soluble 2-substituted aminopyrido[2,3-d]pyrimidin-7-yl ureas. structure-activity relationships against selected tyrosine kinases and exploration of in vitro and in Vivo anticancer activity. J. Med. Chem. 2001, 44, 1915-1926.

[5] Afgennas, G.B.; Mologni, L.; Ahmed, S.; Rajaratnam, M.; Marin, O.; Lindholm, N.; Viltadi, M.; Gambacorti-Passerin, C.; Scapozza, L.; Yli-Kauhaluoma, J. Design, Synthesis, and biological activity of urea derivatives as anaplastic lymphoma kinase inhibitors. Chem. Med. Chem. 2011, 6, 1680-1692.

[6] Limban, C.; Chifiriuc, M.C.B.; Missir, A.V.; Chiruta, I.C.; Bleotu, C. Antimicrobial activity of some New thioureides derived from 2-(4-chlorophenoxymethyl)benzoic acid. Molecules 2008, 13, 567-580.

[7] Venkatachalam, T.K.; Mao, C.; Uckun, F.M. Effect of stereochemistry on the anti-HIV activity of chiral thiourea compounds. Bioorg. Med. Chem. 2004, 12, 4275-4284.

[8] Kaymakcioglu, B.K.; Rollas, S.; Korcegez, E.; Ariciooglu, F, Synthesis and biological evaluation of new N-substituted-N'-(3,5-di/1,3,5-trimethylpyrazole-4-yl)thiourea/urea derivatives. Eur. J. Pharm. Sci. 2005, 26, 97-103.

[9] Aramadaka, S.K.; Guha, M.K.; Prabhu, G.; Kini, S.G.; Vijayan, M. synthesis and evaluation of urea and thiourea derivatives of oxazolidinones as antibacterial agents. Chem. Pharm. Bull. 2007, 55, 236-240.

[10] Esteves-Souza, A.; Pissinate, K.; Nascimento, M.G.; Grynberg, N.F.; Echeveria, A. Synthesis, cytotoxicity, and DNA-topoisomerase inhibitory activity of new asymmetric ureas and thioureas. Bioorg. Med. Chem. 2006, 14, 492-499.

[11] MDL, MDDR Database, Houghten. J. Comb. Chem. 2003, 2, 189.

[12] Yao, J.; Chen, J.; He, Z.; Sun, W.; Xu, W. Design, synthesis and biological activities of thiourea containing sorafenib analogs as antitumor agents. Bioorg. Med. Chem. 2012, 20, 2923-2929.

[13] Shantharam, C.S.; Suyoga, V.D.M.; Suhas, R.; Sridhara, M.B.; Channe, G.D. Inhibition of protein glycation by urea and thiourea derivatives of glycine/proline conjugated benzisoxazole analogue Synthesis and structure-activity studies. Eur. J. Med. Chem. 2013, 60, 325-332. 
Novel naphthalene-1,5-diamine containing urea/thiourea derivatives

[14] Yang, W.; Hu, Y.; Yang, Y.S.; Zhang, F.; Zhang, Y.B.; Wang, X.L.; Tang, J.F.; Zhong, W.Q.; Z Zhu, H.L. Design, modification and 3D QSAR studies of novel naphthalin-containing pyrazoline derivatives with/without thiourea skeleton as anticancer agents. Bioorg. Med. Chem. 2013, 21, 1050-1063.

[15] Keche, A.P.; Hatnapure, G.D.; Tale, R.H.; Rodge, A.H.; Kamble, V.M. A novel pyrimidine derivatives with aryl urea, thiourea and sulfonamide moieties: synthesis, anti-inflammatory and antimicrobial evaluation. Bioorg. Med. Chem. 2012, 22, 6611-6615.

[16] Burgeson, J.R.; Moore, A.L.; Boutilier, J.K.; Cerruti, N.R.; Gharaibeh, D.N.; Lovejoy, C.E.; Amberg, S.M.; Hruby, D.E. Tyavanagimatt SR, Allen, RD. SAR analysis of a series of acylthiourea derivatives possessing broad-spectrum antiviral activity. Bioorg. Med. Chem. Lett. 2012, 22, 4263-4272.

[17] Upadhayaya, R.S.; Kulkarni, G.M.; Vasireddy, N.R.; Vandavasi, J.K.; Dixit, S.S.; Chattapadhayaya, S.V. Design, synthesis and biological evaluation of novel triazole, urea and thiourea derivatives of quinoline against Mycobacterium tuberculosis. Bioorg. Med. Chem. 2009, 17, 4681-4692.

[18] Khan, S.A.; Singh, N.; Saleem, K. Synthesis, characterization and in vitro antibacterial activity of thiourea and urea derivatives of steroids. Eur. J. Med. Chem. 2008, 43, 2272-2277.

[19] Sett, P.P.; Ranken, R.; Robinson, D.E.; Osgood, S.A.; Risen, L.M.; Rodgers, E.L.; Migawa, M.T.; Jefferson, E.A.; Swayze, E.E. Aryl urea analogs with broad-spectrum antibacterial activity. Bioorg. Med. Chem. Lett. 2004, 14, 5569-5572.

[20] Naidu, K.R.M.; Kumar, M.A.; Dadapeer, E. Synthesis and antioxidant activity of novel 15-alkyl/aryl-

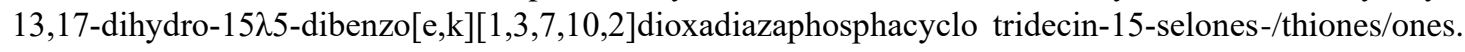
J. Heterocycl. Chem.2011, 2, 317-322.

[21] Dadapeer, E.; Naidu, K.R.M.; Raju, C.N. Synthesis and thermal study of phosphorus containing dendron using 2-butyne-1, 4-diol at the core. Arab. J. Chem. 2016, 11, S1265-S1271.

[22] Dadapeer, E.; Naidu, K.R.M.; Raju, C.N. Facile iterative synthesis, spectral characterization, electron microscopic study and thermogravimetric analysis of phosphorus dendron with bisphenol A at the focal point. J. Iran. Chem. Soc. 2102, 4, 513-519.

[23] Naidu, K.R.; Reddy, K.R.K.K.; Kumar, C.V.; Raju, C.N. Sharma, D.D. A facile catalyst-free Pudovik reaction for the synthesis of $\alpha$-amino phosphonates. S. Afr. J. Chem. 2009, 62, 185-188.

[24] Tian, M.; Zhao, X.; Wu, X.; Hong, Y.; Chen, Q.; Liu, X.; Zhou, Y. Chemical composition, antibacterial and cytotoxic activities of the essential oil from Ficus tikoua bur. Rec. Nat. Prod. 2020, 14, 219-224

[25] Utsukarci, B.S.; Gurdal, B.; Bilgin, M.; Satana, D.; Demirci, B.; Tan, N.; Mat, A. biological activities of various extracts from Salvia cassia sam. ex rech.f. and chemical composition of its most active extract, Rec. Nat.Prod. 2019, 13, 24-36

$$
\underset{\substack{\text { publications } \\ \text { (C) } 2021 \text { ACG Publications }}}{\mathrm{C}}
$$

